\title{
Revitalisasi Spirit Pemikiran Etika Gus Dur
}

\section{Faizatun Khasanah}

Universitas Islam Negeri Syarif Hidayatullah Jakarta

Faizatunkhasanah1@gmail.com

Abstract: In this Modern era, human being identic with positivistic and materialistic thinking. In this step human out of religious and philosophic thinking. That gives impact to morality that lose from believe in God. This is urgency of this research at modern global era. Writer use philosophical approach and critical method. The result of this research is characteristic of Gus Dur ethic it's religious-rational. The foundation of Gus Dur ethic is religious teaching, God gives human some of excess that are reason, moral and feel. From that, human have to responsibility to keep universe especially to human being, not to self-interest. Gus Dur ethic that based on religious and ratioanl approach is appropriate in this modern era, especially at Indonesian state, because Gus Dur is the figure that rise up Indonesian Islam (Islam Nusantara).

Abstrak: $\quad$ Manusia modern identik dengan serba matrealistik dan positifistik, pada tahapan ini manusia sudah lepas dari pemikiran religius dan pemikiran filosofis yang masih global. Cara pandang ini juga berpengaruh terhadap sikap moral seseorang yang mulai meninggalkan hal-hal yang bersifat supranatural. Di sini letak urgensi pemikiran etika Gus Dur di era global yang hampir mengalami kepincangan. Penilitian ini bertujuan mengetahui corak pemikiran etika Gus Dur dan urgensinya di zaman modern, dalam dunia filsafat post modern. Menggunakan pendekatan filsafat dan metode analisis-kritis, sehingga ditemukan corak pemikiran etika Gus Dur yang bersifat Religius-Rasional. Pangkal tolak pemikiran etika Gus Dur berangkat dari postulat Tuhan menganugrahkan kepada manusia berupa akal, budi dan perasaan. Sehingga dengan piranti ini manusia berkewajiban untuk berbuat baik terhadap alam semesta, tidak hanya mengejar duniawi 
semata. Di zaman modern dibutuhkan pola pikir yang bersifat rasional namun di sisi lain nilai-nilai agama mulai ditinggalkan. Sehingga rumusan etika Gus Dur yang berangkat dari premispremis agama dengan pendekatan rasionalnya dan dalam konteks keindonesiaan perlu untuk dihidupkan kembali, Karena Gus Dur berkeislaman khas Indonesia (Islam Nusantara).

Kata Kunci: Etika, Religious, Rasional, Pemikiran Modern, Gusdur

\section{A. Pendahuluan}

Pembahasan mengenai etika tidak lekang oleh waktu (up to date), karena sebagai kompas perilaku moral yang bersifat universal. Dari zaman yunani kuno (Plato, Aristo dan seterusnya) sampai zaman post modern masih diperbincangkan. Di era globalisasi moral mengalami degradasi sehingga etika eksistensinya menjadi semakin urgent. Pembahasan mengenai etika dalam kajian filsafat merupakan cabang dari aksiologi yaitu ilmu pengetahuan yang mempelajari hakikat nilai. Salah satu bagian yang merupakan penjelasan-penjelasan dalam filsafat yang membicarakan masalah predikat baik (good) dan buruk (bad) dalam arti susila (moral) dan asusila (immoral). Predikatpredikat tersebut tidak akan mempunyai makna apapun (meaningless) bila tidak terwujud dalam tindakan manusia di alam empiris, dengan kata lain etika merupakan filsafat praktis. ${ }^{1}$ Predikat-predikat itu pada bentuk kualitasnya mengacu pada satu sisi dari dua sisi yang saling beroposisi, yakni pada sisi baik atau susila. Apabila seseorang mengantarkan simbol pada bentuk atribut yang sesuai dengan pendapat dan aturan umum maka dapat dikatakan bahwa tindakan tersebut bersusila, baik dan juga etis. Sehingga pada sisi baik dan bersusila disebut etika Sebaliknya orang yang tidak sesuai dengan kebiasaan umum komunitasnya maka disebut sebagai orang yang tidak baik, tidak bersusila, tidak etis dan dianggap melanggar etika. ${ }^{2}$

Penyelidik bangsa Arab yang terbesar mengenai etika adalah Ibnu Miskawaih dalam bukunya (Tahdzibul Akhlaq wa al- 'Araq), yang wafat pada $421 \mathrm{H}$. Dia mencampurkan ajaran Plato, Aristoteles,

${ }^{1}$ De Vos, Pengantar Etika (Yogyakarta: PT. Tiara Wacana Yogya, 2002), 23 see more; John Lewelyn and Emmanuel Levinas, The Genealogy of Ethics, (New York: Routledge, 1995), 25.

${ }^{2}$ De Vos, Pengantar Etika, 24. 
Galinus dengan ajaran Islam. Ajaran Aristoteles banyak tentang penyelidikan jiwa. ${ }^{3}$ Yang menarik dari pemikiran Ibnu Miskawaih adalah ia berusaha meramu apa yang ada dalam al-Quran (religious) dan mengkombinasikannya dengan filsafat Yunani kuno (rasional) sejauh tidak bertentangan dengan Quran. Al-Kindi $801 \mathrm{M} / 185 \mathrm{H}$ adalah filsuf pertama Islam juga telah berbicara mengenai etika, namun belum selengkap Ibnu Miskawaih. Pandangannya mengenai etika berkaitan dengan keutamaan manusia adalah budi pekerti itu sendiri. Kemudian Ia membagi keutamaan-keutamaan itu dalam tiga bagian yaitu: kebijaksanaan, keberanian dan kesucian. Ketiga keutamaan itu lahir dari sikap adil (menjadi basis moral Gus Dur).

Kemudian Ibnu Rusyd 510 H/1126 juga berbicara mengenai etika, Ia membenarkan teorinya Plato yang mengatakan bahwa manusia adalah makhluk sosial yang membutuhkan kerjasama untuk memenuhi kebutuhan hidup dan mencapai kebahagiaan. Untuk merealisasikan kebahagian yang merupakan tujuan akhir dari manusia diperlukan bantuan agama yang akan meletakkan dasar-dasar akhlak secara praktis. Selain itu, bantuan Filsafat yang mengajarkan tentang keutamaan teoritis untuk itu diperlukan perhubungan dengan akal aktif. $^{4}$

Teori di atas menunjukkan pentingnya etika yang menjadi topik pembahasan dari masa ke masa. Pada ranah praktik, etika menjadi semakin penting lagi ditengah kegersangan spiritual akibat pola berfikir yang serba positivistik dan materealistik. Sehingga, hanya bertumpu pada satu aspek rasional, padahal di dalam diri manusia selain akal ada rasa (dzauq) yang akan melahirkan sikap moral. Etika merupakan alat untuk mengkritisi dan sekaligus sebagai acuan dalam menentukan nilai baik dan buruk yang terformulasikan menjadi moral. Apalagi di tengah hantaman gelombang modernisasi, perubahan yang terus terjadi itu muncul di bawah hantaman kekuatan yang mengenai semua segi kehidupan, yaitu gelombang modernisasi. Yang dimaksud modernisasi di sini bukan hanya menyangkut barang atau peralatan yang diproduksi semakin canggih, melainkan juga cara berpikir yang telah berubah secara radikal. Ada banyak cara berpikir yang

${ }^{3}$ Ahmad Mahmud Subkhi, Al-Falsafah al-Akhlaqiyyah Fil Fikri al-Islami (Kairo, 1992), 17. 126.

${ }^{4}$ Hasyimiyah Nasution, Filsafat Islam (Jakarta: Gaya Media Pratama, 1999), 
berkembang, seperti rasionalisme, individualisme, nasionalisme, sekularisme, materialisme, konsumerisme, pluralisme religius serta cara berpikir dan pendidikan modern yang telah banyak mengubah lingkungan budaya, sosial dan rohani masyarakat.

Oleh sebab itu penulis merasa perlu untuk menghidupkan kembali gagasan pemikiran etika Gus Dur (1940-2009). Pemikiran etika Gus Dur tidak bisa dilepaskan dari kondisi sosial politik ketika itu. Gus Dur merupakan salah satu pemikir Indonesia yang secara terbuka tidak setuju dengan adanya formalisasi Islam sebagai bentuk Negara. Ketika itu lembaga-lembaga non formal yang dalam asalnya "Islam" menghendaki menjadi lembaga formal yang berasaskan Islam. Menurut Gus Dur lembaga-lembaga tersebut tanpa mencantumkan nama Islam sebagai asas formalnya, tetap akan dikenal oleh masyarakat sebagai lembaga Islam jika sepak terjangnya menunjukkan moral Islam. Islam bukan hanya sekedar aturan kelembagaan, melainkan menjadi spiritualitas yang menggerakkan kearah kepedulian sosial dan keadilan.

Penelitian ini akan membahas corak pemikiran Gus Dur dengan melihat kondisi sosio hitoris pada masanya dan kondisi sosio politik sekarang. Dengan mengetahui corak etika Gus Dur maka diambil spirit/semangat etikanya untuk dihidupkan kembali dimasa sekarang. Karena Gus Dur adalah Figur Sentral di Indonesia. penulis menemukan beberapa pola pemikiran dan aksi moralnya Gus Dur ke dalam beberapa bagian, yaitu: etika politik dengan prinsip keadilannya, etika sosial dengan prinsip empati, etika beragama dengan prinsip toleransi (tasamuh), serta etika ekonomi dengan prinsip kesejahteraan merata.

Penelitian ini menggunakan metode analisis-kritis dan pendekatan filosofis, ${ }^{5}$ Objek formal penelitian ini adalah etika Gus Dur

${ }^{5}$ Anton Bakker and Achmad Charris Zubair, Metodologi Penelitian Filsafat, (Yogyakarta: Kanisius, 1990), 60 Dalam pendekatan filosofis dalam memahami hakikat realitas yang terdalam dibagi kedalam beberapa pendekatan lagi, pertam:ontologik (mencari hakikat realitas yang terdalam, misalnya: filsafat hukum, filsafat agama dll), kosmologik ( mempelajari hakikat sesuatu yang terdalam yang berkaitan dengan ruanag, waktu, dinamika gerak), logika (menggunakan logika deduktif [formal] dan logika induktif [material], teologis mengaitkan antara fenomena empiris rasional dan kekuatan supra natural [Tuhan], kebenaran mutlak adalah milihNya dan dengan taat kepada ajaran agama akan mencapai hakikat tertinggi), etika (berdasarkan pada nilai norma yang berlaku di masyarakat atau nilai 
itu sendiri sedangkan objek material dari penelitian ini adalah pemikiran tokoh yakni etika berdasarkan pada karya-karya Abdurrahman Wahid dan pandangan-pandangan orang lain mengenai Gus Dur.

Beberapa tulisan yang juga membahas tenang etika perspekif Gusdur adalah Mibtadin, Humanisme dalam Pemikiran Abdurrahman Wahid. Tesis ini menjelaskan posisi pemikiran humanisme Gus Dur sebagai basis antropologis yang dibangun atas pribumisasi Islam, kosmopolitanisme dan universalitas Islam. Humanismenya Gus dur yang berdasar pada al-kulliyat al-khomsah dan diarahkan pada pemberdayaan civil society. Dalam penelitian ini juga dijelaskan tipikal humanismenya Abdurrahman Wahid merupkan humanisme religious, namun Mibtadin juga menjelaskan aspek rasionalitas dan peran sentral manusia dalam menjalankan humanismenya. Untuk konteks keindonesiaan, Abdurrahman Wahid adalah sosok yang selalu meggembar-gemborkan tentang nilai-nilai universal, demokrasi, keadilan, kesetaraan gender, HAM, dan kebebasan.

Abd. Salam, Etika Sosial Abdurrahman Wahid, 2014. Dalam skripsi ini dicari motif etika sosial Abdurrahman wahid yang memahami islam secara kritis demi tergeraknya rukun sosial serta mencari relevansi etika Gus Dur dalam kehidupan socsial. Kesimpulan dalam penelitian ini adalah akhlaq merupakan cita mulia untuk menghindari "kemungkaran social". Etika menjadi kewajiban kesadaran memahami tugas ketuhanan sebagai tugas kemanusiaan untuk merespon masalah-masalah kemiskinan, diskriminasi dan toleransi. Oleh karena itu, Islam tidak dipandang sebagai agama yang rigid, namun bisa merespon masalah-masaah kemanusiaan.

Greg Barton dalam bukunya "Gagasan Islam liberal di Indonesia: Pemikiran Neo Modernisme Nurcholish Madjid, Djohan Effendy, Ahmad Wahid dan Abdurrahman Wahid" (1999). Dalam buku ini Greg Barton menjelaskan bahwa Abdurrahman Wahid dimasukkan kedalam tokoh Neo Modernisme. Ciri khas dari NeoModernisme adalah memadukan antara corak pemikiran tradisional dan modern. ${ }^{6}$ Robert W. Hefner dalam bukunya "Islam Pasar

pragmatis, nilai fungsiona yang mampu membentuk keunggulan etika manusia dalam proses kehidupan). Lihat, Sunata, dkk. (2006). 1999).

${ }^{6}$ lihat Greg Barton, Gagasan Islam Liberal Indonesia (Jakarta: Paramadina, 
Keadilan” Artikulasi Lokal Kapitalisme dan Demokrasi “(2000). Abdurrahman Wahid dinilai sebagai pemikir Islam Indonesia yang telah membuka jalan dialogis berbagai kalangan termasuk non Muslim dalam rangka mewujudkan persatuan dan kebersamaan. Selain itu, Hefner juga memberikan penjelasan bahwa Indonesia merupakan Negara yang pluralis sehingga terdapat potensi yang besar dalam mewujudkan tradisi demokrasi. Dinamika demokrasi Islam Indonesia bukan pada saat Islam bersatu dengan kekuasaan Negara, tetapi pada saat independensi kelompok Islam melakukan kooptasi. ${ }^{7}$ dari beberapa tulisan diatas belum ada yang menuliskan secara kompehensif pemikiran etika Gusdur sesuai dengan kondisi sosial pada masanya dan kondisi politik pada masa sekarang.

\section{B. Pengertian Etika Religious Rasional}

Secara Religius, sesuatu dianggap baik adalah sesuatu yang sesuai dengan kehendak Tuhan, sedangkan perbuatan buruk adalah sesuatu perbuatan yang tidak sesuai dengan kehendak Tuhan. ${ }^{8}$ Dalam Islam keimanan memegang peranan penting dalam menentukan perbuatan baik dan buruk. Iman mempunyai pengaruh yang signifikan dalam meluruskan kepribadian seseorang dan membersihkan dirinya dari kecenderungan pada keburukan. Iman menjadi stimulus yang mendorong seseorang dalam bertindak. Muslim sejati seyogyanya selalu merasa diawasi oleh Allah, sehingga perbuatanya dapat terkontrol. Sebagaimana QS. Al- Hadid (54):4 dan QS.An-Nisa' (4):1. Iman tidak hanya berpengaruh terhadap pribadi seseorang tetapi terhadap masyarakat. Menurut Maududi, Iman kepada Allah dijadikan sebagai motif untuk mematuhi hukum susila dan rasa tanggung jawab untuk berbuat yang baik dan menghindari kejahatan. Menurut Poedjawijatma aliran ini adalah aliran yang paling baik dalam praktiknya. Kehendak Tuhan terwakili dalam agama-agama dan kitab suci yang dibawakan oleh para utusan-Nya. Dalam hal ini penulis akan memaparkan aliran religiosisme dalam Islam. Dalam Islam sendiri

${ }^{7}$ Robert W Hafner, Islam Pasar Keadilan: Artukulasi Lokal Kapitalisme Dan Demokrasi (Yogyakarta: LKIS, 2000), 35.

${ }^{8}$ Islam menjadikan Allah sebagai titik tolak dan sumber bagi ajaran moral. Menurut Maududi Tuhan lah yang patut dijadikan sebagai sumber moral keseluruhan lihat; Hafner, Islam Pasar Keadilan: Artukulasi Lokal Kapitalisme Dan Demokrasi, 51. 
aliran Akhlak secara garis besar dibagi menjadi dua kelompok, yaitu rasionalisme yang diwakili muktazilah dan aliran intuisionalis yang diwakili madzhab sufi.

Etika religious dalam Islam dibagi ke dalam dua tipe, yaitu rasional dan intuisi (tasawuf). Gus Dur cenderung ke arah tipe rasional, meskipun Ia termasuk pemimpin kaum tradisional. Aliran Muktazilah mewakili madzhab rasionalisme dalam pemikiran Islam, karena mereka membuktikan bahwa kepercayaan yang diterima melalui wahyu dijelaskan menggunakan argumen rasional. Selain itu, muktazilah menempatkan posisi akal yang tinggi bahkan ekstrem (jika nash bertentangan dengan akal maka menurut muktazilah lebih condong ke akal dan teks agama harus ditafsirkan). Mereka membangun madzhabnya di atas landasan rasional. Sebagaimana piranti-piranti yang telah diberikan Allah kepada mannusia adalah akal, sehingga menempatkan manusia pada posisi yang tinggi.

\section{Latar Sosial Politik Pemikiran Etika Gus Dur}

Orde baru adalah masa pemerintahan sebelum Gus Dur menjadi presiden. Pemerintahan ini diusung oleh Pak Harto dengan ciri kepemimpinan "demokrasi terpimpin". Tipe kepemiminan Pak Harto adalah sentralisasi, kebebasan mengeluarkan pendapat dan berekpresi secara bebas tidak mendapatkan ruang di publik. Banyak terjadi pembredelan pers-pers yang di nilai Pak Harto mengancam kedudukannya. Selain pers usaha kecil menegah (UKM) juga diatur oleh pemerintah. Pemerintahan pada masa itu sangat erat dengan kekerasan dan pemaksaan dimana sanksi kriminal diberikan pada pemberontak, tetapi di sisi lain kemakmuran rakyat terjamin, barangbarang pemenuhan hidup dapat diakses dengan mudah akibat dari pinjaman-pinjaman besar ke luar negeri untuk mensejahterakan ekonomi rakyat. Namun, disisi lain berakibat pada tingginya hutang Indonesia ke luar negri.

Mulai 1997 setelah kondisi politik-sosial-ekonomi mulai tidak stabil, maka terjadilah penindasan oleh pemerintahan. Hal tersebut merupakan pengrusakan aspek sosial di masyarakat. Pemaksaan institusi untuk kepentingan politik dilakukan karena tuntutan akan kestabilan di pemerintahan. Namun pada masa itu pula kesenjangan sosial semakin meningkat akibat kebijakan yang berorientasi 
pertumbuhan dan melupakan pemerataan serta distribusi yang adil. Beratnya hukuman yang akan ditimpakan kepada orang-orang yang sekiranya dapat menjadikan ancaman bagi pemerintah membuat masyarakat umum memilih diam. Pemikiran-pemikiran yang terpendam membuat konflik tersendiri di beberapa kalangan baik perseorangan maupun golongan.

Kondisi sosial serta politik pada masa Orde baru terasa mencekam mengingat otoritas pemerintah yang tidak bisa diganggu gugat serta aturan-aturan main yang tentunya bersanksi berat jika dilanggar. Ancaman yang berkelanjutan membuat banyak pihak mencoba berontak secara sembunyi-sembunyi. Anggota pemerintahan sendiri juga takut dengan para pemimpin pusat, sehingga sistem yang ada tidak bisa diubah begitu saja. Keterikatan akan HAM yang disalah artikan oleh bangsa membuat kebijakan-kebijakan yang dibuat pemerintah semakin sulit dipahami.

Pemikiran-pemikiran Gus Dur merupakan anti-tesis dan sintesis dari pola kepemimpinan sebelumnya. Dimana Gus Dur menggembar-gemborkan adanya demokrasi, kebebasan, desentralisasi (ekonomi, budaya) dan perlindungan hak-hak minoritas. Dalam hal kenegaraan pemikiran Gus Dur berangkat dari kegelisahan filosofis atas otoritarianisme Negara. Pemikiran ini memberikan perlindungan atas kekerasan yang dilakukan oleh oknum politik yang mengatasnamakan Negara. Kekerasan itu meliputi dua aspek, pertama: kekerasan represif yag diperankan oleh aparat penegak hukum, Undang-Undang dan peradilan. Kedua: kekerasan koersif yang membuat kekuasaaan Negara untuk membentuk masyarakat yang sesuai dengan standar nilai. ${ }^{9}$

Gus Dur tidak setuju dengan anggapan yang pertama, ia tidak lagi menjelma sebagai konstitusi bagi penindasan Negara akan tetapi sebagai perlindungan dari ketertindasan rakyat itu sendiri. Konstitusi pada hakikatnya mengatur tentang kekuasaan dan hubungan kekuasaan di dalam Negara, memberi batas tegas pada wewenang kekuasaan Negara dan sekaligus meneguhkan hak-hak warganegaranya berikut menjamin perlindungan baginya. Konstitusi justru diadakan untuk menjamin warganegara dari kemungkinan kesewenang-wenangan

${ }^{9}$ Jeans Bartelson, The Critique of the State (UK: Cambride University Press, 2001), 114-19. 
kekuasaan Negara. Hal ini didasarkan pada faham bahwa pemegang kekuasaan memang bisa menyalahgunakan kekuasaan. Demokrasi ala Gus Dur lahir dari keprihatinan ini. Sang pembuat kebijakan publik berada dalam ruang publik itu sendiri. Dimana ada ruang bersama, tempat semua masyarakat merumuskan kepentingan bersama bukan kepentingan kelompoknya. Dengan menggunakan asas keadilan dan egaliter, pemerataan ekonomi.

Kondisi sosial politik pada masa sekarang hampir sama dengan masa Gus Dur, salah satunya tipe-tipe pemimpin pada masa Gus Dur dan sekarang selaras, mengingat penyalahgunaan kekuasan masih banyak terjadi. Dalam masalah sosial angka kemiskinan tinggi dan stratifikasi sosial masih mencolok. Hal ini dapat dilihat dari berita setiap hari yang menyiarkan para pemimpin negeri ini seolah acuh terhadap kepentingan rakyatnya. Jika dilihat dari kacamata aliran etika utilitarianisme yang menekankan asas kemanfaatan, bahwa dalam membuat kebijakan pemerintah harus mempertimbangkan asas kemanfaatan terbesar dari masyarakat. Sehingga, tujuan hukum adalah memberikan kemanfaatan dan kebahagiaan sebanyak-banyaknya kepada warga masyarakat yang didasari oleh falsafah sosial yang mengungkapkan bahwa setiap warga negara mendambakan kebahagiaan, dan hukum merupakan salah satu alatnya. ${ }^{10}$

\section{Pemikiran Etika Gus Dur}

Definisi ${ }^{11}$ pada sebuah kata mempunyai beragam pengertian, karena sebuah kata mempunyai banyak makna tergantung dari konteks pembicaraannya. Seorang tokoh mendefinisikan sebuah kata juga dipengaruhi oleh latar belakang pendidikan dan konsen pemikiran yang

${ }^{10}$ Darji Darmodihardjo, in Filsafat Hukum; Edisi Lengkap (Dari Klasik Sampai Postmoderenisme), by Hyronimus Rhiti (Yogyakarta: Penerbit Universitas Atma Jaya, 2011), 159.

11 Definisi berfungsi agar tidak terjadi kesimpangsiuran dalam penggunaanya. Definisi merupakan bagian dari ilmu logika atau dalam bahasa arab disebut dengan ta'rif. Mendifinisikan adalah menyebutkan sekelompok karakteristik suatu kata sehingga dapat mengetahui pengertiannya sea dapat membedakan kata lain yang mempunyai arti lain pula lihat; Dari sisni ada dua jenis yaitu genera (jenis) dan differentia (sifat pembeda), sehingga tepatnya mendefinisikan adalah menganalisis jenis dan sifat pembeda yang dikandungnya Harold C.Martin, The Logic and Rethoricas Eposition, (New York: Rinehart\&company Inc, 1959), 9; Mundiri, Logika (Jakarta: Raja Grafindo Persada, 2010), 37-38. 
ia bidangi. Abdurrahaman Wahid atau kerap disapa Gus Dur mendefinisikan istilah etika agak berbeda dengan pengertian secara umum. Disesuaikan dengan konteks keindonesiaan. Inilah dasar definisi etika Abdurrahman Wahid yang dijelaskannya secara implisit dalam karya-karyanya.

Gus Dur berkeyakinan bahwa manusia pada dasarnya memiliki kedudukan yang mulia dan tinggi berkat anugerah Tuhan berupa kapasitas-kapasitas yang mereka miliki. Keyakinan primordial ini lalu diterjemahkan oleh Gus Dur, dengan cara menempatkan secara cermat keyakinan itu ke dalam problematika hubungan antara takdir Tuhan dan kehendak bebas manusia. Kecermatan itu terutama dapat dijumpai pada saat mana ia menempatkan hubungan kehendak manusia dan takdir Tuhan dalam kerangka ilmu pengetahuan alam/sosial dan filsafat moral. Dengan cara demikian, Abdurrahman Wahid berhasil menampilkan konsepsi manusia dan moralitas menurut kosmologi Islam dalam wajahnya yang lebih fungsional dan universal. Sedemikian rupa sehingga "moralitas-agama Islam" bersama dengan "moralitas agama-agama" pada umumnya dan "moralitas-sekuler" dapat turut serta memberi sumbangan tak ternilai harganya bagi penyelenggaraan kehidupan masyarakat di dunia yang puspa-ragam dan bagi masa depan kebangunan peradaban. ${ }^{12}$

Gagasan Abdurrahman Wahid tentang manusia dan moralitas pada hakikatnya dibangun dari wawasan kosmologi Islam, khususnya dunia pesantren. Paling tidak ada tiga konsep mendasar tentang "manusia", yakni:(1) kedudukannya yang tinggi dihadapan makhluk lain; (2) statusnya yang mulia sebagai khalifah di bumi; dan (3) kemampuan inteleknya dalam merumuskan masalah dasar kemanusiaan. Ketiga-tiganya adalah fitrah manusia yang diyakini sebagai anugerah Tuhan sang Pencipta, sehingga manusia berhak atas kedudukan mulia baik di hadapan Tuhan maupun ciptaan lain di alam semesta.

Pertama-tama, kedudukan tinggi manusia itu diperoleh lantaran anugerah akal, budi, dan perasaan. Ketiga properti asali yang diberikan Tuhan Sang Pencipta itu memungkinkan manusia sanggup memupuk diri serta mengembangkan daya dan potensi kebaikannya di

12 Abdurrahman Wahid, Islamku, Islam Anda, Islam Kita: Agama Masyarakat Negara Demokrasi (Jakarta: The Wahid Institute, 2006), 54-58. 
dunia. Kendatipun Abdurrahman Wahid tidak menyediakan definisi pembeda yang jelas dan terpilah antar ketiganya, namun secara bersama-sama properti dasar itu mencirikan keadaan manusia yang berbeda dengan makhluk-makhluk yang lain sekaligus status yang mulia kepadanya. Memang benar, kata Abdurrahman Wahid, manusia juga berpotensi jatuh dalam kesalahan dan bahkan kehinaan atau menyalahgunakan fitrah mulia itu, namun "pada dasarnya ia adalah tetap makhluk yang mulia yang dilengkapi dengan budi, akal, perasaan dan ketrampilan untuk mengembangkan diri yang seolah-olah tanpa batas"13. Mafhum muwafaqah-nya, berkat fitrah atau kapasitaskapasitas yang dimilikinya dasar manusia adalah makhluk merdeka yang selalu terbuka terhadap aneka kemungkinan, yang di dalamnya mencakup kemungkinan untuk mengembangkan potensi kebaikan dalam dirinya dan potensi-potensi lain yang membawa manfaat bagi kehidupan semesta.

Dalam arti itu maka sifat "keterbukaan" sendiri hakikatnya telah ada di dalam diri manusia dan melekat di dalam kapasitas pengembangan dirinya. Selama ia masih hidup, manusia berpotensi memajukan diri, menyerap aneka wawasan kehidupan, mengembangkan kebaikan-kebaikan serta ikut menyumbang pada kemaslahatan dan kemanfaatan. Keterbukaan memungkinkan manusia bereksistensi secara dinamis. Manusia sebagai makhluk mengada (human being) dan selalu dalam proses menjadi (human becoming) yang sifatnya ad infinitum. Manusia memang dapat berkembang menjadi buruk, tapi penilaian tersebut tidak serta merta dapat dijatuhkan kepada potensi "baik" manusia itu sendiri yang merupakan anugerah Ilahi, hingga akhir hayatnya yang final. Cukuplah dinyatakan dalam bahasa yang 'rendah hati' bahwa manusia pada dasarnya berpotensi baik. Dengan demikian, pikiran, kebijakan dan tindakan yang mau "mematikan" proses manusia dalam "menjadi" (becoming), maka serentak kiranya merupakan gangguan bagi kemerdekaan dan keterbukaan diri manusia dalam merealisasikan aneka daya potensi baik itu yang dalam jangka panjang merupakan syarat kemungkinan bagi kebudayaan dan lahirnya peradaban umat manusia.

Selain fungsi pengembangan diri di atas, kosmologi Islam memberi kedudukan khusus kepada manusia sebagai khalifah fil-ardh.

13 Abdurrahman Wahid, Islam Kosmopolitan, Nilai-Nilai Indonesia \& Transformasi Kebudayaan (Jakarta: The Wahid Institute, 2007), 30.

Analisis: Jurnal Studi Keislaman, Volume 19, No. 1, Juni 2019 
Pengertian "khalifah" sendiri adalah wakil Allah atau vicegerent yang bertugas menjalankan kekuasaan Allah di bumi manusia. Secara umum khalifah juga bermakna pemimpin, pengatur, pemelihara, pelindung dan seterusnya. Dalam kapasitas itu, keberadaan manusia adalah menjalankan fungsi sosial-kemasyarakatan yang dibedakan dari kapasitas fungsi pengembangan diri yang hakikatnya bersifat individual. Mengenai fungsi sosial ini, Abdurrahman Wahid mendasarkan diri pada firman Allah: "Laqad kaana lakum fi rasulillahi uswatun hasanah" (telah ada bagi kalian keteladanan sempurna dalam diri Rasulullah). Keteladanan yang dimaksud terutama peranan Nabi Muhammad SAW dalam mengusahakan kesejahteraan bagi seluruh umat manusia (rahmatan lil alamin).Fungsi ini mencakup keharusan untuk memperjuangkan kesejahteraan secara menyeluruh dan tuntas, sekaligus melawan pola hidup sosial yang eksploitatif, tidak manusiawi dan tidak berasaskan keadilan. ${ }^{14}$

Dalam kapasitas itu juga maka manusia berhak menyandang kedudukan mulia sebagai aktor sejarah. Manusia, dalam pandangan Abdurrahman Wahid, adalah "pelaku yang bermartabat dan berderajat penuh" yang diharapkan "ikut ambil bagian dalam kebangunan peradaban manusia". ${ }^{15}$ Dan justeru pada tahap sebagai aktor sejarah inilah, menurut Abdurrahman Wahid, saat yang paling menentukan bagi status kemuliaan manusia di hadapan Allah SWT sebagaimana dinyatakan dalam Al-Quran: "laqad karramna bani adam”(sungguh telah Kumuliakan anak Adam).

Kapasitas fakulatif ketiga yang dimiliki manusia adalah karunia akal dan pikiran. Abdurrahman Wahid menyebut daya ini sebagai "kemampuan fitri, akli dan persepsi kejiwaan manusia untuk hanya mementingkan masalah-masalah dasar kemanusiaan belaka"16. Pengertian ini kiranya terkait erat dengan fungsi intelek manusia berupa kapasitas konsepsional untuk mengenali, mengidentifikasi, membeda-bedakan, menggolongkan, dan memahami gejala-gejala alam/sosial, serta menangkap masalah-masalah kehidupan secara esensial. Termasuk di dalam fungsi itu adalah kapasitas untuk

14 Abdurrahman Wahid, Pergulatan Negara, Agama Dan Kebudayaan (Depok: Desantara, 2001), 153.

15 Wahid, Islam Kosmopolitan, Nilai-Nilai Indonesia \& Transformasi Kebudayaan, 13.

${ }^{16}$ Ibid., 70. 
menimbang-nimbang yang terbaik bagi dirinya maupun masyarakat secara umum dari aneka pilihan yang tersedia dalam realitas kehidupan. Adapun produk kegiatan intelek adalah filsafat dan ilmu pengetahuan beserta teknologi sebagai turunannya.

Sehingga dari penjelasan di atas dapat ditarik kesimpulan bahwa etika menurut Abdurrahman Wahid adalahsejumlah nilai dan pola perilaku social yang bertalikan pencapai tujuan dengan kemuliaan cara yang digunakan. Tata nilai dan pola perilaku itu yang disebut sebagai akhlak karimah. Manusia itu fitrahnya baik, jika terlahir suatu perbuatan yang buruk itu disebabkan karena ketidak seimbangan antara akal, budi dan perasaan. Manusia itu mempunyai kecenderungan untuk menghasilkan perbuatan yang baik karena bersumber dari Tuhan. Meskipun Tuhan mempunyai intervensi dalam mendorong manusia untuk melakukan perbuatan, namun manusia tetap mempunyai kebebasan. Karena disisi lain manusia di bebani tanggung jawab yang tinggi di bumi ini yaitu khalifah.

Abdurrahman wahid membagi etika menjadi tiga, yakni Etika politik, etika sosial dan ekonomi, dan etika agama.

1. Etika politik

Dalam pidato keprisidenan Abdurrahman Wahid usai pengambilan sumpah sebagai presiden RI beliau menyampaikan pentingnya menegakkan keadilan dan mewujudkan kesejahteraan.

"Kita tetap berketepatan hati pula untuk tetap menggunakan prinsip-prinsip pencarian keuntungan dan pencarian efisiensi serta penggunaan akal dan budi daya yang kita miliki untuk mematangkan kehidupan kita bersama dan menaikkan pendapatan dari rakyat kita. Ini adalah tugas yang maha berat, bukan tugas yang ringan karena di dalamnya ada implikasi bahwa kita semua, sidang Majlis yang berbahagia, memberikan tugas kepada saya di bawah bimbingan pimpinan MPR yang baru untuk menegakkan keadilan dan untuk mendatangkan kemakmuran bagi sebanyak mungkin warga masyarakat kita". ${ }^{17}$

Dari pidato keprisedenan Abdurrahman Wahid di atas dapat diambil beberapa prinsip etika. Pertama: Penggunaan akal dan budi

17 Ahmad Amir Aziz, Neo-Modernisme Islam Di Indonesia: Gagasan Sentral Nur Cholish Madjid Dan Abdurrahman Wahid (Jakarta: Rineka Cipta, 1999), 106-107. 
daya diperuntukkan untuk kepentingan bersama. Kedua: Prinsip keadilan untuk mewujudkan kemakmuran dan kesejahteraan Rakyat. Dimensi hubungan antar manusia yang menjadi syarat segala hubungan yang baik adalah keadilan. Adil menurut Frans Magnis Suseno bisa diartikan sebagai mengakui orang lain, mengakui dia sebagai manusia dengan martabatnya dengan menghormati hakhaknya ${ }^{18}$. Cinta itu mewujudkan hubungan antara manusia paling mendalam dan berharga, tetapi kalau dia melanggar keadilan dia bukan cinta dalam arti yang sebenaranya. Kejujuran yang tidak adil bukanlah kejujuran. Kebaikan yang tidak adil kehilangan harkat etisnya. Namun, keadilan tidak dapat berdiri sendiri, memperjuangkan keadilan hanyalah etis apabila dilakukan dengan cara yang beradab. Tanpa sikap beradab keadilan menjadi sikap yang tidak adil. Itulah seninya sila kedua "kemanusiaan yang adil dan beradab" yang menjadi ideologi bangsa Abdurrahman Wahid. Dan menjadikan Pancasila sebagai asas kebangsaan Abdurrahman Wahid yang menunjukkan bahwa bangsa Indonesia adalah bangsa yang multikultural dan multi agama.

Dari prinsip etika keadilan di atas, Abdurrahman Wahid mendasarkanya pada sumber Islam (al-Qur'an). Sebuah etika yang mendasarkan argumennya atas agama disebut dengan aliran religious. Dalam surat An-Nisa ayat 135 sebagimana yang dikutip oleh Abdurrahman Wahid di atas jelas memerintahkan manusia supaya berbuat adil. Serta larangan keras untuk meninggalkan keadilan. Abdurrahman Wahid dalam menegakkan keadilan dilakukannya dengan sungguh-sungguh. Sampai sering kali dia digunjing, dikritik berbagai pihak demi untuk menegakkan keadilan itu sendiri.

Ciri etika politik Abdurrahman Wahid selain prinsip keadilan adalah prinsip lemah lembut, anti kekerasan sebagaimana yang dicontohkan oleh Rasulullah berdakwah secara lemah lembut sebagaimana termaktub dalam surah (QS. An.Nahl (16):125). Abdurrahman Wahid menentang adanya tindak kekerasan dalam kancah politik maupun sosial. Sebagaimana terlihat kebijakannya dalam menangani masalah terorisme dan pembelaan terhadap kaum Muslim bahwa sebenarnya antek-antek terorisme itu bukan Islam.

18 Farns Magnis Suseno, Kebangsaan, Demokrasi, Pluralisme: Bunga Rampai Etika Politik Aktual, (Jakarta: Kompas, 2015), 185. 
Mereka yang melakukan serangan terorisme hanya oknum kecil dari Muslim yang tidak paham tentang agama Islam.

\section{Etika Sosial}

Moralitas islam adalah moralitas yang merasa terlibat dengan penderitaan sesama manusia bukanya menghukumi mereka yang menderita. ${ }^{19}$ Abdurrahman Wahid bertutur: "Moralitas yang harus ditumbuhkan haruslah memiliki watak utama yang berupa keterlibatan dalam perjuangan si miskin untuk memperoleh kehidupan yang layak dan penghargaan yang wajar atas hak-hak asasi mereka". ${ }^{20}$

Gus Dur menjelaskan bahwa kaum Muslimin tidak boleh acuh terhadap kerusakan berat yang ditimbulkan karena sikap dan pandangan hidup mereka yang oleh moralitas ganda yang ada. Mereka harus berani untuk mengadakan koreksi atas moralitas ganda yang ada. Membiarkan diri dengan adanya korupsi besar-besaran dengan menyibukkan diri dengan ritus-ritus hanyalah membiarkan berlangsungnya proses pemiskinan bangsan. Lebih lanjut Gus Dur menjelaskan bahwa dalam kondisi seperti ini hanya dengan menumbuhkan moralitas yang berupa keterlibatan dengan mereka yang menderita itulah yang paling utama untuk mengatasi kegersangan moral yang acuh terhadap lingkungan sosial.

Moralitas yang telah tumbuh dalam jiwa yang merasa terlibat dengan mereka yang menderita harus bersifat utuh dalam dirinya, dalam artian tidak terpecah menjadi kepingan-kepingan dan masingmasing untuk diri sendiri dan untuk orang lain. Gus Dur menjelaskan bahwa keutuhan moralitas itu akan membawa integritas yang tinggi dalam sikap dan perbuatan yang menjadi pertanda tingginya martabat seseorang. Bukan mereka yang menyibukkan diri dalam ritual-ritual keagamaan dan penguatan identitas keagamaannya. Dari pernyataannya ini Gus Dur melihat tinggi rendahnya martabat seseorang tidak hanya dapat dilihat dari kesalehan spiritualnya" peribadatannya dengan Tuhan" namun, lebih jauh mereka harus peka dan menumbuhkan empatinya untuk mengatasi masalah sosial yang semakin krusial. Tentunya tetap berpegang teguh pada nilai-nilai agama.

19 Ibid., 4.

${ }^{20}$ Abdurrahman Wahid, Melawan Melalui Lelucon (Jakarta: Tempo, 2000), 3. 
Masalah sosial adalah tanggung jawab bersama, tidak hanya mengandalkan peran pemerintah. Namun, harus dimulai dari diri sendiri. Manusia yang di beri mandaat dari Allah untuk menjadi pemimpin dimuka bumi harus mampu untuk melaksanakan tanggung jawab itu dengan amanah.

Tanggung jawab moral kepada kemanusiaan timbul dari kenyataan bahwa umat manusia sedang menderita dalam ukuran massif hampir disemua bidang kehidupan.

Masalah sosial yang menjadi perbiancangan Gus Dur dintaranya yaitu masalah hak asasi manusia. Dalam tulisannya yang berjudul "Mencari Perspektif Baru dalam Menegakkan Hak Asasi Manusia". ${ }^{21}$ Masalah hak asasi manusia tidak hanya di derita oleh rakyat Indonesia, namun sudah memasuki masalah internasional. Penanganan masalah hak asasi manusia menurut Gus Dur di perlukan adanya upaya-upaya yang serius dan sitematisasi kebijakan yang menyaeluruh, dengan jalan pengendapan pemikiran dan penyederhanaan masalah itu sendiri (guna penyususnan yang lebih mantap bobotnya, tetapi lebih jauh jangkaunnya). Kebijakan itu guna memenuhi hak asasi manusia yang lebih realistik.

Hukum agama mejadi pijakan etika sosial Gus Dur dalam membuat kebijakannya namun tidak berbentuk formal. Pernyataannya yaitu: "Hukum agama tidak akan hilang kebesaranya dengan berfungsi sebagai etika masyarakat. Bahkan kebesaranya akan memancar karena ia mampu mengembangkan diri tanpa dukunagn masif dari institusi yang bernama negara."

Gus Dur menggunakan pendekatan sejarah dalam menggambarkan masalah hak asasi manusia yang sifatnya global. HAM yang di lontarkan oleh Amerika Serikat lewat Carternya sudah tidak kedengaran lagi yang baru muncul beberapa tahun sudah tidak ada lagi. Bersamaan dengan itu carter mundur dari kebijaksanaan semula. Hal ini berarti bahwa pukulan berat bagi aspirasi perjuangan HAM di Korea. Park Cung Hee terbunuh dan bentuk pemerintahan yang lebih longgar mulai berkembang di Korea selatan. Sedangkan karena pembelaanya terhadap masa lampau bekas Syech Iran yang penuh penindasan, Carter dihadapkan pada dua hal yang saling

${ }^{21}$ Abdurrahman Wahid, Prisma Pemikiran Gus Dur (Yogyakarta: LKIS, 1999), 85. 
bertentangan. Yaitu tidak berdayanya AS menangani masalah penyanderaan warganya di Teheran dan yang kedua dakwaan para mahasiswa Iran akan penggunaan para diplomat sebagai mata-mata Negara lain. Menurut Gus Dur hal itu berarti bahwa adanya pelanggaran keadaulatan disamping pelanggaran hak asasi manusia, bangsa Iran untuk tidak di mata-matai.

Lebih lanjut, Gus Dur menjelaskan bahwa para penguasa represif mampu memutar asumsi HAM yang dilancarkan oleh Carter. Ferdinan Marcos naik ke mimbar sebuah forum internasional dalam bidang HAM dan menyuarakan aspirasi "keadilan ekonomi dalam skala internasional sebagai prasyarat bagi tercapainya perlakuan berperikeadilan bagi warga negara secara perseorangan. Dengan lantang menteri luar negeri sebuah Negara berkembang memberikan klaim terhadap perjuangan kemanusiaan. "walaupun ada tahanan politik di tempat kami, tetapi pemerintah kami dengan gigih memperjuangkan terwujudnya orde ekonomi internasional baru sebagi kerangka umum perjuangan kemanusiaan. ${ }^{22}$

Abdurrahman Wahid merupakan tokoh yang sangat gigih dalam memperjuangkan toleransi beragama dalam masyarakat majemuk. Bagi Wahid, toleransi bukan persoalan epistemologi sehingga membutuhkan definisi, tetapi aksiologi dari konsep-konsep yang bersifat normative dalam Islam. Ia hadir bersamaan dengan topik pembahasan pluralisme. Jika pluralisme membicarakan soal bagaimana realitas kemajemukan agama dapat diterima, maka toleransi adalah lebih menekankan bagaimana berperilaku dalam kemajemukan tersebut. Perilaku ini yang dalam etika menjadi topik pembahasan.

\section{Etika Beragama}

Toleransi menurut Gus Dur sesungguhnya bukanlah gagasan yang berdiri sendiri, tetapi menyatu dengan dimensi sosial dalam frame besar kehidupan berbangsa. Secara teoritik, toleransi dalam pemikiran Gus Dur ini juga bukan pemikiran yang terpisah dengan dimensi keagamaan (ulumuddin), tetapi merupakan proses dialogis antara keilmuan Islam (ulumuddin) dengan keilmuan humaniora yang menghasilkan sikap dan tindakan toleran sebagai aksiologinya. Sebagimana prinsip keadilan politik sebelumnya Abdurrahman Wahid

${ }^{22}$ Ibid., 86-87.

Analisis: Jurnal Studi Keislaman, Volume 19, No. 1, Juni 2019 
juga mendasarkan pikirannya pada agama dan juga nalar serta daya upaya manusia.

Sebagai seorang muslim gagasan toleransi Abdurahman Wahid tidak terlepas dari dimensi normatif dalam Islam yang tertuang dalam ayat berikut 23: "Dan tiadalah Kami mengutus kamu, melainkan untuk (menjadi) rahmat bagi semesta alam" Bagi Abdurrahman Wahid, kata rahmatan lil 'alamin dalam ayat ini bukan sekedar mengandung arti sebagai umat manusia semata, lebih jauh lagi ia memahaminya sebagai semua makhluk yang ada di dunia ini. Dengan kata lain, Islam dalam pandangannya adalah sebagai pelindung semua makhluk. ${ }^{24}$

Konteks perlindungan sebagaimana dimaksud oleh Abdurrahman Wahid di atas, bukan dalam kerangka perbandingan mayoritas-minoritas ataupun kuat-lemah, melainkan sebuah tanggung jawab yang mengarah pada terbentuknya suatu ikatan persaudaraan. Hal ini didasarkan pada hadis yang berbunyi "irhamuu man fil ardhi yarhamukum man fil sama", (sayangilah orang yang ada di bumi maka akan sayang pula mereka yang ada di langit kepadamu). (HR. Ahmad, Abu Dawud, Tirmidzi dan Hakim).$^{25}$

Dalam QS. Al-Baqorah (2) 208, Abdurrahman Wahid mengartikna kata "as-silmi" dalam konteks yang lebih luas, tidak hanya diartikan sebagai sistem islam, namun diartikan sebagai pengayom. ${ }^{26}$ Menurutnya, toleransi diminta oleh al-Qur'an, yang berarti bahwa Islam adalah pelindung bagi semua orang termasuk kaum non-muslim. Surat ini juga sesuai dengan QS.Al-Anbiya (21):107 "wa ma arsal naka illa rahmatan lil'aamin". Islam bukan berarti penghapusan terhadap semua agama yang telah ada. Islam menawarkan dialog dan toleransi dalam bentuk saling menghormati. Islam menyadari bahwa keragaman umat manusia dalam agama dan keyakinan adalah kehendak Allah maka dari itu tak mungkin disamakan.

23 Muhammad Husein Haikal, Sejarah Hidup Muhammad (Jakarta: Intermasa, 1992), 199-205.

${ }^{24}$ Wahid, Islamku, Islam Anda, Islam Kita: Agama Masyarakat Negara Demokrasi, 76.

${ }^{25}$ HR. Ahmad, Abu Dawud, Tirmidzi dan Hakim, dishahihkan oleh Syaikh Al Albani dalam Shahihul Jaami' no. 3522 .

${ }^{26}$ Wahid, Islamku, Islam Anda, Islam Kita: Agama Masyarakat Negara Demokrasi. 
Al-quran dijadikan sebagai pedoman normatif sebagai dasar etika oleh Abdurrahman Wahid. Al-Qur'an tidak dipahami secara tekstualis, meskipun ia mewakili kaum tradisionalis. Abdurrahman Wahid menyampaikan bahwa, toleransi tidak hanya diartikan sebagai sikap saling menghargai, mengakui, keberadaan yang lain. Namun, Lebih jauh megartikan toleransi sebagi sikap merasakan apa yang mereka rasakan (sense of belonging) terhadap kaum-kaum yang terpinggirkan. Ini berarti bahwa pemahaman tentang konsep toleransinya tidak bisa terlepas dari prinsip humanisnya.

Dari penjelasan di atas Abdurrahman Wahid menggunakan alQuran sebagi dasar etikanya sekaligus logika dalam penalarannya. Abdurrahman Wahid adalah seorang nasionalis sejati, ia bangga dengan Indonesia dan Islam nya maka ia tidak takut kalau harus membela agama-agama lain. Ia mantap dengan keislamannya. Selain dasar al-Qur'an Abdurrahman Wahid mengkontekskan pemkirannya dengan kondisi sosial politik di Indonesia. Pancasila sebagai ideologi bangsa Indonesia dijadikan juga sebagai ideologianya secara utuh. Dalam sila yang pertama Ketuhanan Yang Maha Esa, dijadikan Abdurrahman Wahid sebagai asas tolerasi dan memperjuangkan hakhak agama lain selain Islam.

\section{Kritik etika Gus Dur}

Gus Dur mendapat julukan tokoh yang kontroversial, teka-teki, nyeleneh, bahkan tidak konsisten melekat pada dirinya. Namun, sebagaimana biasanya Abdurrahman Wahid menanggapi predikatpredikat tersebut dengan enteng, "gitu aja kok repot". Sebagian dari peneliti Abdurrahman Wahid ada yang mengatakan bahwa Abdurrahman Wahid tidak konsisten, hal ini dikarenakan sikap Abdurrahman Wahid yang terlalu zig-zag dan melawan arus. Hal seperti itu sah-sah saja, karena Abdurrahman Wahid diperlakukan sebagai teks wacana yang bisa di tafsirkan dari berbagai segi, tergantung dari arah mana penafsir menafsirkan pemikiran dan sikap Abdurrahman Wahid. Menurut penulis dilihat dari kacamata etika Abdurrahman Wahid tetap seorang Gus Dur dari dulu sampai sekarang. Terkadang Abdurrahman Wahid bersikap berbelok arah namun tetap pada tujuan awalnya. Diibaratkan kita mau berjalan ke arah utara pada proses menuju ke utara kita boleh berbelok ke timur, barat bahkan berseberangan arah menuju ke selatan sebentar dan kemudian kembali ke arah tujuan awal utara. Itulah zig-zag pemikirannya. Kalau melihat 
sikap kecil-kecilnya Abdurrahman Wahid kadang orang dibuat bingung yang jika di lihat secara sepintas berseberangan dengan prinsip awalnya.

Diantara sikap zig zag Abdurrahman Wahid dalam bidang politik yaitu, pada awalnya Abdurrahman Wahid tidak setuju dengan ikut terjun secara langsung dalam politik praktis dan partai Islam. Namun pada perkembangan situasi sosial politik yang mendesak Abdurrahman Wahid terjun dalam politik praktis dan membawahi parpol Islam (PKB). Ia ikut menjadi pemrakarsa PKB yang pada jargonya merupakan parpol non sektarian. Namun pengikutnya orang muslim semua. Hal ini tampak kontradiktif karena Abdurrahman Wahid sebagi ketum PBNU melarang NU untuk ikut terjun ke ranah politik praktis ia "menggembar gemborkan" untuk kembali ke "khittah 26" bahwa NU harus menemukan identitasnya sebagai organisasi keagamaan dan sosial dan melupakan aktifitas politik sebelumnya baik partai tersendiri maupun PPP. Serta lebih jauh lagi Abdurrahman Wahid mau menerima tawaran menjadi presiden yang pada awalnya ia mendukung poros Megawati (PDI-P).

Banyak pihak yang menyesalkan hal ini, salah satunya yaitu Dr. Eka dalam tulisanya yang berjudul "Tokoh kontroversial, Isu Kontroversial" menggambarkan situasi ini "memaksakan benda berharga masuk ke dalam karung yang terlalu kecil, benda itu karena terlalu besar akan lecet karena tidak muat, begitupun karungnya akan jebol karena kebesaran muatan". Maksudnya, Abdurrahman Wahid adalah tokoh yang lebih besar dari pada hanya seorang presiden, sedikit saja orang yang diuntungkan dengan hal ini dan banyak orang yang terluka. ${ }^{27}$

Salahuddin Wahid adiknya sendiri mengungkapkan bahwa Abdurrahman Wahid sering berubah sikap untuk memperbaiki sikap awalnya, sehingga di anggap plin-plan. Salahuddin tidak tahu latar belakangnya apa dan kenapa Abdurrahman Wahid melakukan hal itu. Ketika Gus Dur menyatakan sikap pada berbagai masalah dan kemudian membantahnya kembali. Salahuddin memberikan contoh pada saat menjelang pemilu 1997 Abdurrahman Wahid mendekati Tutut untuk tujuan tertentu. Padahal tidak lama sebelumnya ia

27 Tim Penyusun, Gila Abdurrahman Wahid: Wacana Pembaca Abdurrahman Wahid (Yogyakarta: Lkis, 2000), 25. 
menunjukkan kedekatannya dengan Mega, hal itu menurut kacamata mereka mengandung resiko politik yang tinggi.

Dalam masalah demokratisasi, Abdurrahman Wahid adalah tokoh yang giat dalam memperjuangkan demokrasi. Tetapi menurut Slamet Effendi di kalangan NU Abdurrahman Wahid sering bertindak yang tidak demokratis. Pada Munas Foksika September 1999 Abdurrahman Wahid menyatakan bahwa "kita harus menjaga konstitusi walaupun dengan cara yang tidak konstitusional". ${ }^{28}$ "memperjuangkan demokrasi dengan cara yang tidak demokratis" bisa diibaratkan dengan sikap Abdurrahman Wahid yang sepertinya tidak konsisten, bahwa tujuan ia ke utara tapi jalannya berbelok-belok. Bahkan terkadang berbalik arah.

\section{E. Relevansi pemikiran Etika Gus Dur}

Abdurrahman Wahid menekankan adanya prinsip berkeadilan guna mencapai kesejahteraan bersama. Jadi, pemerintah harus bersikap adil terhadap semua lapisan masyarakat tanpa kecuali. Rakyat yang menjadi priorits para pemimpin, tidak hanya memperkaya diri sendiri. Mereka peduli terhadap kaum minoritas sehingga mereka tidak semakin terpojokkan. Dengan mengakui mereka sebagai manusia dan memperlakukan mereka sebagai manusia maka keadilan disini harus ditegakkan guna mencapai kesejahteraan bersama. Abdurrahman Wahid sering kali dalam tulisannya menekankan adanya prinsip etika keadilan dalam tubuh pemerintahan. Ia menempatkan keadilan sebagai basis etika yang sangat penting, "pemerintahan yang adil walaupun dipimpin oleh seorang yang kafir adalah lebih baik dari pada dipimpin oleh seorang Muslim yang dhâlim" Menurut Abdurrahman Wahid dengan adanya keadilan dalam politik dan hukum maka keadilankeadilan yang lainnya (sosial, keagamaan) bisa masuk kedalamnya.

Selain bersikap adil seorang pemimpin harus mampu bersikap amânah karena mengemban tanggung jawab yang besar yaitu sebagai wakil Tuhan di bumi dan di sisi lain sebagai wakil dari rakyat. Sehingga seorang pemimpin dalam kaitanya dengan ekonomi harus dapat menjaga dan mengelola kekayaan alam yang dimiliki Negara untuk kemaslahatan rakyat yang sebesar-besarnya. Masyarakat patuh

${ }^{28}$ Ibid., 59.

Analisis: Jurnal Studi Keislaman, Volume 19, No. 1, Juni 2019 
kepada pimpinan sejauh mana ia dapat mengelola kekayaan alam dan mengemban tanggung jawabnya dengan penuh tanggung jawab. Prinsip keadilan dan tanggung jawab (amanah) harus ditumbuhkan dalam diri para wakil rakyat, dengan memanusiakan manusia dan memperlakukan mereka sebagai manusia. Sehingga akan terpenuhi hak dan tanggung jawab mereka. Tanggung jawab mereka sebagai khalifah di bumi untuk berbuat kebaikan.

Adil dan amanah merupakan sikap moral yang harus ditumbuhkan dalam jiwa para pemimpin. Sikap seperti ini yang ditunjukkan dan di perjuangkan oleh Gus Dur pada waktu itu dan masih relevan sampai sekarang ini, melihat para pemimpin negri ini banyak yang tidak amanah apalagi adil. Bisa dilihat baru-baru ini di tahun 2018 yaitu tujuh (7) kepala daerah menjadi tersangka KPK pada bulan Februari ${ }^{29}$, kemudian dilajutkan pada bulan Juli jumlahnya bertambah menjadi sembilan belas (19) kepala darah terjerat korupsi juga. ${ }^{30}$ Melihat hal ini terjadi paradoks, dimana Indonesia yang mayoritas Islam yang telah menyediakan pedoman nilai moral yang lengkap dan di sisi lain semua yang di tangkap KPK 90\% juga beragama Islam. Statement Gus Dur yang mengatakan bahwa nilainilai agama hanya menjadi hiasan belaka terbukti kebenarannya.

Dalam bidang sosial, sekarang ini banyak sekali tragedi kemanusiaan karena rendahnya moralitas. Nilai-nilai etika yang di bangun oleh Gus Dur masih relevan pada masa sekarang, yaitu semangat humanismenya yang di tumbuhkan melalui karakter empati dari dalam diri. Nilai empati yang ditekankan Gus Dur hadir dari dalam diri yang merasa terlibat langsung dengan penderitaan kaum miskin dan mereka yang menderita. Sehingga, jiwa kemanusiaan kita akan terpanggil untuk membantu dan mengangkat derajat mereka yang tertindas. Semangat semacam ini sangat diperlukan bagi para mereka yang menempati posisi high class dalam masyarakat. Sehingga, akan terjadi pemerataan kesejahteraan, tidak hanya dinikmati para pemegang kuasa.

Terlihat dalam beberapa kasus sosial yang perlu penanganan secara serius dan totalitas yang datang dari dalam jiwa sebagai rasa

${ }^{29} \mathrm{https}: / /$ nasional.kompas.com/read/2018/02/15/08153641/belum-gena

30 http://kabar24.bisnis.com/read/20180728/16/821663/parah-ini-deretan19-kepala-daerah ibid. 
empati. Sebagaimana tragedi kemanusiaan yang terjadi di Ghouta Timur (Suriah) antara pemerintah Suriah dan kelompok yang bertikai, banyak sekali memakan korban jiwa. $^{31}$ Mereka tidak hanya membutuhkan bantuan berupa materi (makanan, kesehatan, tempat tinggal) tetapi juga dukungan moral dan motivasi. Banyak anak-anak dan wanita yang sudah renta mengalami nasib yang tidak jelas dan teraniaya. Sebagai manusia apakah hanya diam saja melihat keadaan seperti ini, ataukah merasa ikut menagis dan terpanggil untuk membantunya. Disini pentingnya empati itu di terapkan. Abdurrahman Wahid menekankan adanya perasaan yang merasa terlibat langsung dengan penderitaan para mereka yang menderita. Sehingga jiwa terdorong untuk memanusiakan manusai dan membantu penderitaan mereka. Sebagai makhluk yang mempunyai hati nurani setidaknya terpanggil melihat tragedi kemanusiaan seperi itu.

Sebagaimana juga pada kasus yang lain, disepanjang perjalan banyak sekali pengemis jalanan menjadi pemandangan di sepanjang perjalanan. Dalam bahasa Abdurrahman Wahid kita posisikan diri kita yang mejadi pengemis itu, berada pada posisi mereka. Sehingga kita dapat merasakan pederitaan mereka. Inilah nilai empati yang ingin di bangun Abdurrahman Wahid dan masih relevan pada masa sekarang.

Dalam bidang sosial keagamaan, prinsip toleransi (tasamuh) antar agama dalam rangka menciptakan kerukunan dan keharmonisan antar umat beragama. Sehingga lahirlah persatuan dan kesatuan. Prinsip ini yang di anut Abdurrahman Wahid dari awal perjuangan hingga akhir hayatnya. Toleransi akan terbentuk ketika terjadi dialog antar umat beragama. Namun, dialog tersebut benar-benar membuka mata dan telinga terhadap apa yang didialogkan. Tidak sekedar dialog yang sudah menyimpan dan mempertahankan argumen sebelumnya. Dialog yang benar-benar hidup dan perasaan saling menghormati. Toleransi yang di usung Abdurrahman Wahid benar-benar teraplikasi dalam pemikiran dan perbuatannya. Benar-benar mendasari sikap nya terhadap agama-agama yang ada sehingga melahirkan sikap yang inklusif. Prinsip semcam ini yang masih relefan pada masa sekarang, melihat corak keberagamaan yang ekslusif dan ingin menampilkan formalisme agama masing-masing pada masa sekarang.

31 http://www.tribunnews.com/nasional/2018/02/27/dunia-internasionalharus-hentikan-tragedi-kemanusiaan-di-ghouta-timur ibid.

Analisis: Jurnal Studi Keislaman, Volume 19, No. 1, Juni 2019 
Beragam organisasi dan partai politik yang ingin membawa bendera Islam sebagai satu-satunya wadah yang sah. Seperti: FPI (Front Pembela Islam), LDII (Lembaga Dakwah Islam Indonesia), SI (Serikat Islam), HTI (Hizbut Tahrir Indonesia), ICMI (Ikatan cendekiawan Muslim Indonesia) dan organisasi Islam lainnya yang mengkotak-kotakkan aliran mereka. Antara aliran satu dan lainnya saja mereka saling berebut kebenaran, mereka mengklaim bahwa aliran mereka yang paling benar. Bagaimana dengan yang berada di luar Islam? maka disini perlunya sikap toleransi yang tinggi dengan adanya keanekaragaman. Kerena di dalam hadist Nabi juga telah disebutkan bahwa umatnya akan terpeceah menjadi 72 Golongan. Maka dengan terpecahnya menjadi banyak golongan akan rawan adanya perpecahan di kalangan intern umat beragama. Dengan berpegang pada toleransi dan saling menghargai akan tercipta kerukunan. Serta menyadari bahwa di luar sana banyak keanekaragaman.

Konflik antar umat beragama diantaranya kerusuhan yang terjadi di Poso Sulawesi Tengah, yaitu konflik agama antara Islam dan Nasrani. Kerusuhan itu mengakibatkan banyak kerugian. Terbagi menjadi tiga bagian, pertama konflik yang terjadi tanggal 25-29 Desember 1998, konflik kedua taggal 17-21 April 2000 dan konflik ketiga terjadi antara 16 Mei hingga 15 Juni 2000. Meskipun kerusuhan itu tidak murni hanya konflik agamamelainkan juga konflikpolitik dan ekonomi, namun agama juga disini turut menjadi faktor belakang kerusuhan itu terjadi. Banyak korban jiwa dan harta benda yang diakibatkan oleh kerusuhan tersebut. Disini perlunya menghidupkan toleransi antar umat beragama. Toleransi tidak hanya berarti menghargai namun juga memahami kondisi mereka yang berbeda. Sehingga tidak saling tuding menuding serta saling mengklaim kebenaran diantara agama satu dengan lainnya.

Dalam kehidupan pribadi Gus Dur, ada beberapa sikap yang patut di contoh dan masih relevan sampai sekarang ini. Diantarannya pribadi yang sederhana, Abdurrahman Wahid lebih sering memakai angkutan umum daripada mobil pribadinya. Meskipun ketika itu ia sudah menjadi ketua PBNU beberapa kali periode. Beliau juga berpakaian sederhana tidak menunjukkan pangkatnya. Sering memakai sandal jepit dan kemeja lengan pendek serta mengenakan sarung. Sampai dia menjadi Presiden RI tetap seperti itu. Salah satu pribadi yang patut di contoh pada masa sekarang, karena para pejabat Negara 
sekarang ini banyak yang hidup bermewahan dan memperlihatkan kekayaanya. Pakaian Branded dan mobil mewah yang berderet. Inilah salah satu contoh perilaku hidup sederhana Gus Dur yang masih relefan sampai sekarang ini.

Pribadi selanjutnya yaitu rela berkorban dan pemaaf. Abdurrahman Wahid rela dicaci maki dan di sudutkan oleh pihakpihak yang tidak setuju dengannya dan bahkan kaumnya sendiri ikut menyudutkannya. Hal itu ia lakukan demi untuk membela mereka yang tertindas dan tidak mendapatkan haknya. Sikap semacam ini yang sudah jarang ditemukan pada pemimpin kita sekarang ini. Karena banyak sekali pemimpin kita sekarang ini yang hanya mengejar kepentingan pribadinya di banding dengan kesejahteraan dan kepentingan rakyat.

Dari pemaparan di atas dapat dilihat relevansi pemikiran etika Gus Dur pada masa sekarang. Gus Dur berangkat dari keprihatinan pribadinya sebagi seorang humanis dan berdasarkan pada dasar agama maqosid as-syari'ah. Gus Dur mengkorelasikannya dengan menggunakan logika berfikir dalam lingkup Indonesia, sehingga spirit pemikiran etikanya masih bisa di teladani dan dirasakan sampai sekarang. Diantaranya yaitu mengenai perjuangannya terhadap etis Cina, mereka bisa duduk berdmapingan dengan pribumi, sampai beliau dijuluki sebagai bapak Kong $\mathrm{Hu}$ Chu Indonesia.

\section{F. Kesimpulan}

Dari pemaparan di atas dapat disimpulkan bahwa etika menurut Gus Dur adalah sejumlah nilai dan pola perilaku sosial yang bertalikan pencapai tujuan dengan kemuliaan cara yang digunakan. Tata nilai dan pola perilaku itu yang disebut sebagai akhlak karimah. Tata nilai moral (etika) berdasarkan pada nash al-Qur'an dan didekati/interpretasikan dengan dalil-dalil rasional sehingga bersifat kontekstual. Selain al-quran Gus Dur juga menggunakan hadist-hadist dan maqosid assyari 'ah sebagai landasan berfikir dan praktik etikanya. Gus Dur menggunakan premis-premis dan penarikan kesimpulan dengan menggunakan logika berfikir dan menjunjung tinggi 3 asas fluktuatif yang dianugrahkan Tuhan kepada manusia yaitu, akal, budi dan perasaan. Perjuangan etika Gus Dur mencakup 3 hal yaitu, etika politik, etika sosial ekonomi, dan etika beragama. Berdasarkan pijakan 
perumusan dan perjuangan etika Gus Dur dapat ditarik benang merah bahwa etikanya merupakan etika yang bercorak Religius-Rasional. Spirit pemikiran dan relevansi pemikiran etika Gus Dur masih bisa dirasakan dan diteladani di era digital sekarang ini. Prinsip keadilan dalam etika politik, nilai ini masih cocok digunakan melihat realitas politik Indonesia sekarang ini. Prinsip empati dalam etika sosial, sangat diperlukan melihat kasus pelanggaran HAM banyak terjadi disekitar. Perasaan empati akan membawa seseorang untuk turut terpanggil secara otomatis untuk terlibat aktif dalam penyelesaiannya. Prinsip toleransi dalam etika Bergama juga masih relevan mengingat banyak sekali sekte-sekte/aliran keagamaan banyak bermunculan. [.] 


\section{Referensi}

Aziz, Ahmad Amir. Neo-Modernisme Islam Di Indonesia: Gagasan Sentral Nur Cholish Madjid Dan Abdurrahman Wahid. Jakarta: Rineka Cipta, 1999.

Bakker, Anton, and Achmad Charris Zubair. Metodologi Penelitian Filsafat,. Yogyakarta: Kanisius, 1990.

Barton, Greg. Gagasan Islam Liberal Indonesia. Jakarta: Paramadina, 1999.

C.Martin, Harold. The Logic and Rethoricas Eposition,. New York: Rinehart\&company Inc, 1959.

Darji Darmodihardjo. In Filsafat Hukum; Edisi Lengkap (Dari Klasik Sampai Postmoderenisme), by Hyronimus Rhiti, 159. Yogyakarta: Penerbit Universitas Atma Jaya, 2011.

De Vos. Pengantar Etika. Yogyakarta: PT. Tiara Wacana Yogya, 2002.

Hafner, Robert W. Islam Pasar Keadilan: Artukulasi Lokal Kapitalisme Dan Demokrasi. Yogyakarta: LKIS, 2000.

Haikal, Muhammad Husein. Sejarah Hidup Muhammad. Jakarta: Intermasa, 1992.

Jeans Bartelson. The Critique of the State. UK: Cambride University Press, 2001.

Lewelyn, John, and Emmanuel Levinas. The Genealogy of Ethics, . New York: Routledge, 1995.

Mundiri. Logika. Jakarta: Raja Grafindo Persada, 2010.

Nasution, Hasyimiyah. Filsafat Islam. Jakarta: Gaya Media Pratama, 1999.

Subkhi, Ahmad Mahmud. Al-Falsafah al-Akhlaqiyyah Fil Fikri alIslami. Kairo, 1992.

Suseno, Farns Magnis. Kebangsaan, Demokrasi, Pluralisme: Bunga Rampai Etika Politik Aktual,. Jakarta: Kompas, 2015.

Tim Penyusun. Gila Abdurrahman Wahid: Wacana Pembaca Abdurrahman Wahid. Yogyakarta: Lkis, 2000. 
Faizatun Khasanah

Wahid, Abdurrahman. Islam Kosmopolitan, Nilai-Nilai Indonesia \& Transformasi Kebudayaan. Jakarta: The Wahid Institute, 2007.

_. Islamku, Islam Anda, Islam Kita: Agama Masyarakat Negara Demokrasi. Jakarta: The Wahid Institute, 2006.

_. Melawan Melalui Lelucon. Jakarta: Tempo, 2000.

-. Pergulatan Negara, Agama Dan Kebudayaan. Depok: Desantara, 2001.

__. Prisma Pemikiran Gus Dur. Yogyakarta: LKIS, 1999. 